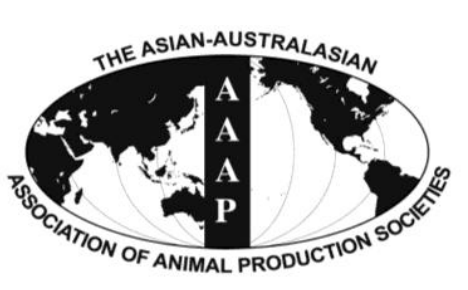

Open Access

Asian Australas. J. Anim. Sci.

Vol. 28, No. 2 : 215-222 February 2015

http://dx.doi.org/10.5713/ajas.14.0321

www.ajas.info

pISSN 1011-2367 elSSN 1976-5517

\title{
Addition of a Worm Leachate as Source of Humic Substances in the Drinking Water of Broiler Chickens
}

\author{
S. Gomez-Rosales ${ }^{1, *}$ and M. de L. Angeles \\ National Center of Disciplinary Research in Animal Physiology, National Institute of Research in Forestry, \\ Agriculture and Livestock, Ajuchitlan, Queretaro, CP 76280, Mexico
}

\begin{abstract}
The objective of this research was to evaluate the growth performance, the apparent ileal digestibility of nitrogen and energy, the retention of nutrients and the apparent metabolizable energy corrected to zero nitrogen retention (AMEn) in broiler chickens supplemented with increasing doses of a worm leachate (WL) as a source of humic substances (HS) in the drinking water. In Exp. 1, 140 male broilers were penned individually and assigned to four WL levels $(0 \%, 10 \%, 20 \%$, and 30\%) mixed in the drinking water from 21 to 49 days of age. Water was offered in plastic bottles tied to the cage. In Exp. 2, 600 male broilers from 21 to 49 days of age housed in floor pens were assigned to three levels of WL $(0 \%, 10 \%$, and $20 \%)$ mixed in the drinking water. The WL was mixed with tap water in plastic containers connected by plastic tubing to bell drinkers. The results of both experiments were subjected to analysis of variance and polynomial contrasts. In Exp. 1, the daily water consumption was similar among treatments but the consumption of humic, fulvic, and total humic acids increased linearly $(\mathrm{p}<0.01)$ as the WL increased in the drinking water. The feed conversion $(\mathrm{p}<0.01)$ and the ileal digestibility of energy, the excretion of dry matter and energy, the retention of dry matter, ash and nitrogen and the AMEn showed quadratic responses $(p<0.05)$ relative to the WL levels in drinking water. In Exp. 2, the increasing level of WL in the drinking water had quadratic effects on the final body weight, daily weight gain and feed conversion ratio $(p<0.05)$. The addition of WL as a source of HS in the drinking water had beneficial effects on the growth performance, ileal digestibility of energy, the retention of nutrients as well on the AMEn in broiler chickens; the best results were observed when the WL was mixed at levels of $20 \%$ to $30 \%$ in the drinking water. (Key Words: Broilers, Humic Substances, Production, Ileal Digestibility, Nutrient Balance)
\end{abstract}

\section{INTRODUCTION}

The benefits of antibiotic growth promoters on the health and growth of animals has been well documented in the scientific literature, as well as the arguments against the extended use of antibiotic growth promoters that could lead to the development of resistant pathogenic bacteria, which represents a serious health risk to animals and man. For this reason, during the last decade, several new additives have been tested as growth promoters to avoid the excessive use of antibiotics or at least reduce or alternate their inclusion in feeds, whilst maintaining an efficient animal production to

\footnotetext{
* Corresponding Author: S. Gomez-Rosales. Tel: +52-419-2920033, Fax: +52-419-2920033, E-mail: gomez.sergio@inifap.gob.mx

1 Faculty of Higher Studies Cuautitlan, UNAM, Ajuchitlan, Queretaro, CP 76280, Mexico.

Submitted Apr. 30, 2014; Revised Jul. 12, 2014; Accepted Sept. 1, 2014
}

obtain safe edible products such as poultry meat and eggs (Islam et al., 2005; Gomez et al., 2012).

Many feed additives have been evaluated; among them, humic substances (HS) have been tested in domestic animals in several studies around the world with promising results. The HS are very common in nature as they originate from the decomposition of organic matter, and are normally present in the drinking water and soil (Islam et al., 2005). Active ingredients of HS consist of humus, humic acid (HA), fulvic acid (FA), ulmic acid, and some microelements (Senn and Kingman, 1973). In veterinary medicine, HS have been used as antidiarrheal agents, pain relievers, immunomodulators and antimicrobials, after the recommendations of the Veterinary Committee of the European Medicine Agency for the Evaluation of Medicinal Products (EMEA, 1999). Antitoxic (Stackhouse and Benson, 1989), anti-inflammatory (Joone and van Rensburg, 2004), 
and immunostimulatory (Joone et al., 2003) properties of HS have been widely studied for human and veterinary medicine to enhance immune potency and health status. Antitoxic properties against dietary excesses of heavy metals in broilers (Herzig et al., 2009) and antiviral activity against herpes simplex and the human immunodeficiency virus have been also reported in research involving HS (Klocking and Helbig, 2005).

In broiler chickens and laying hens, a growth-promoting effect of HS when supplemented in the feeds or drinking water has been recently documented. In broiler chickens, improvements in body weight, feed conversion, ash content of the tibia, as well as reduction in crypt depth and increased length of the villi of the jejunal mucosa due to the inclusion of HS have been reported (Kocabagli et al., 2002; Ozturk and Coskun, 2006; Taklimi et al., 2012). In laying hens and partridges, benefits in feed intake, egg production, egg mass, eggshell thickness and hardness have been observed (Dobrzański et al., 2009; Ozturk et al., 2009).

Most of the HS tested in poultry were commercially available products (derived from lignite) and purified HS were used in some studies. Wormcomposts originating from animal manures have been shown to be good sources of HS with values that vary from $4 \%$ to $9 \%$ of total HS (Islam et al., 2005; Gomez et al., 2011). Furthermore, HS are normally found in low amounts in the liquid or leachates draining from the beds after watering the wormcomposts. Beds of wormcomposts should be constantly watered to maintain an optimum moisture level between $70 \%$ to $80 \%$ for better performance of the worms. Therefore, leachates containing significant amounts of HS are constantly draining from the beds.

It has been shown that the addition of a commercial product as a source of HS through the drinking water improved the feed intake, weight gain, feed efficiency and carcass weight of broiler chickens (Ozturk and Coskun, 2006; Ozturk et al., 2010); however, the use of worm leachate (WL) as natural source of HS has not been tested in broiler chickens. Therefore, the objective of this research was to evaluate the growth performance, the apparent ileal digestibility of nitrogen and energy and the retention of nutrients in broiler chickens supplemented with increasing doses of WL as a source of HS in the drinking water.

\section{MATERIALS AND METHODS}

This research was revised and approved by the Ethical Committee of Animal Use of the National Center of Disciplinary Research in Animal Physiology, National Institute for Research in Forestry, Agriculture and Livestock. Two experiments were carried out in broiler chickens, one in holding pens (Exp. 1) and one in floor pens (Exp. 2), in which the WL was added to the drinking water. In both experiments, the same batch of WL was used. The WL was stored in amber plastic containers throughout the experiments. The WL was obtained from a wormcompost prepared with a mixture of pig and sheep manure. At the beginning of the experiment, a sample of the WL was taken for chemical and microbiological analysis. The content of HA, FA, and total HA (THA) in the WL was $0.47,0.14$ and $0.61 \mathrm{mg} / \mathrm{L}$, respectively (Table 1 ).

\section{Experiment 1}

One hundred and forty Ross B308 male broilers from 21 to 49 days of age were used. Broilers were penned individually in holding mesh-floored cages with a metal feeder and a cup drinker in a naturally ventilated unit and assigned to four WL levels $(0 \%, 10 \%, 20 \%$, and 30\%) mixed in the drinking water. The diets were based on corn and soybean meal and formulated to meet or exceed the nutritional requirements according to the strain and phase of production. A grower diet was used from 21 to 35 days of age and a finisher diet was used from 36 to 49 days of age (Table 2). Anticoccidial drugs and antibiotic growth promoters were not included in the feeds. Water was offered in plastic bottles tied to the cage. The water offered and rejected was quantified and the daily water consumption was calculated. The daily consumption of HA, FA, and THA was estimated by multiplying the content of each of these compounds in the WL by the daily consumption of water. Body weight was registered at the beginning and end

Table 1. Chemical composition of the worm leachate

\begin{tabular}{lc}
\hline Item & Concentration/value \\
\hline Total humic acids (mg/L) & 0.61 \\
Humic acids (mg/L) & 0.47 \\
Fulvic acids (mg/L) & 0.14 \\
pH & 8.48 \\
Total solids (\%) & 2.33 \\
Organic matter $(\%)$ & 0.67 \\
Organic carbon (\%) & 0.39 \\
Total nitrogen (mg/L) & 492.1 \\
Carbon:nitrogen ratio & 7.93 \\
Phosphorus (mg/L) & 361.79 \\
Potassium (mg/L) & $6,482.31$ \\
Calcium (mg/L) & 98.64 \\
Magnesium (mg/L) & 76.52 \\
Sodium (mg/L) & $1,228.58$ \\
Electric conductivity (dS/m) & 13.37 \\
Solubility (\%) & 100 \\
Apparent density (kg/L) & 1.01 \\
Total bacteria (UFC/mL) & 69000 \\
Yeasts (UFC/mL) & $<10$ \\
Total coliforms (UFC/100 mL) & $\mathrm{ND}$ \\
Fecal coliforms (UFC/100 mL) & $\mathrm{ND}$ \\
Salmonella spp. & $\mathrm{ND}$ \\
\hline ND, non &
\end{tabular}

ND, non detectable. 
Table 2. Diet composition for grower and finisher broiler chickens in Exp. 1 and 2

\begin{tabular}{|c|c|c|}
\hline Item & Grower & Finisher \\
\hline Ground corn & 63.98 & 66.43 \\
\hline Soybean meal & 29.67 & 26.66 \\
\hline Vegetable oil & 2.33 & 3.27 \\
\hline Calcium phosphate & 1.23 & 1.00 \\
\hline Calcium carbonate & 1.45 & 1.31 \\
\hline Premix $^{1}$ & 0.70 & 0.70 \\
\hline Sodium bicarbonate & 0.00 & 0.00 \\
\hline Salt & 0.45 & 0.45 \\
\hline DL-methionine & 0.10 & 0.11 \\
\hline L-lysine $\mathrm{HCl}$ & 0.09 & 0.07 \\
\hline \multicolumn{3}{|l|}{ Calculated nutrient content } \\
\hline ME (kcal/kg) & 3,100 & 3,200 \\
\hline $\mathrm{CP}(\%)$ & 19.41 & 18.30 \\
\hline Digestible lys (\%) & 1.00 & 0.91 \\
\hline $\mathrm{Ca}(\%)$ & 0.95 & 0.90 \\
\hline Available P (\%) & 0.48 & 0.45 \\
\hline \multicolumn{3}{|l|}{ Analyzed nutrient content } \\
\hline Dry matter $(\%)$ & 92.56 & 91.54. \\
\hline Ashes $(\%)$ & 5.43 & 5.01 \\
\hline $\mathrm{CP}(\%)$ & 19.00 & 18.35 \\
\hline Gross energy (kcal/kg) & 4,153 & 4,028 \\
\hline \multicolumn{3}{|c|}{$\begin{array}{l}\text { ME, metabolizable energy; CP, crude protein. } \\
{ }^{1} \text { Each kg provides: } 6,500 \mathrm{IU} \text { of vitamin } \mathrm{A} ; 2,000 \mathrm{IPU} \text { of vitamin } \mathrm{D}_{3} ; 15 \\
\text { IU of vitamin } \mathrm{E} ; 1.5 \mathrm{mg} \text { of vitamin } \mathrm{K} ; 1.5 \mathrm{mg} \text { of thiamine; } 5 \mathrm{mg} \text { of } \\
\text { riboflavin; } 35 \mathrm{mg} \text { of niacin; } 3.5 \mathrm{mg} \text { of pyridoxine; } 10 \mathrm{mg} \text { of pantothenic } \\
\text { acid; } 1,500 \mathrm{mg} \text { of choline; } 0.6 \mathrm{mg} \text { of folic acid; } 0.15 \mathrm{mg} \text { of biotin; } 0.15 \\
\mathrm{mg} \text { of vitamin } \mathrm{B}_{12} ; 100 \mathrm{mg} \text { of } \mathrm{Mn} ; 100 \mathrm{mg} \text { of } \mathrm{Zn} ; 50 \mathrm{mg} \text { of Fe; } 10 \mathrm{mg} \text { of } \\
\mathrm{Cu} ; 1 \mathrm{mg} \text { of } \mathrm{I} \text {. }\end{array}$} \\
\hline
\end{tabular}

of the trial and the feed offered and refused was also registered every week to determine the feed intake $(g / d)$, weight gain $(\mathrm{g} / \mathrm{d})$ and feed conversion.

During the last three days of the experiment, total excreta were collected from 15 broilers per treatment. During this period, $180 \mathrm{~g}$ of feed per day, divided in two equal meals, was offered to each bird to minimize feed refusals. The cages were equipped with side metal walls and a tray underneath, in which a plastic bag was placed to collect the excreta from each cage every $24 \mathrm{~h}$. The excreta was weighed and stored frozen at $-20^{\circ} \mathrm{C}$ every day. In addition, during the last week of the experiment, $0.3 \%$ of titanium dioxide was included in the feed as an internal marker for determination of the ileal digestibility of nitrogen and energy. On the last day of the experiment, the ileal contents of 24 chicks per treatment were collected in subgroups of three samples per replicate. Each replicate sample was stored frozen at $-20^{\circ} \mathrm{C}$ in polyethylene bags.

Ileal content and excreta samples were lyophilized and ground using a $2 \mathrm{~mm}$ mesh. Determinations of dry matter, ashes, nitrogen, energy and titanium were done in the experimental finisher diet. Dry matter, nitrogen, energy and titanium were determined in the ileal contents and the ileal digestibility of nitrogen and energy were estimated in a dry matter basis. Dry matter, ashes, nitrogen and energy were also analyzed in excreta to estimate the nutrient balance. All laboratory determinations were carried out following standard procedures. In addition the apparent metabolizable energy corrected to zero nitrogen retention (AMEn) was estimated.

\section{Experiment 2}

Six hundred Ross B308 male broilers from 21 to 49 days of age housed in floor pens (25 birds/pen) were used. Broilers were assigned to three levels of WL $(0 \%, 10 \%$, and $20 \%$ ) mixed in the drinking water. The WL was mixed with tap water in $200 \mathrm{~L}$ plastic containers and placed on a platform that was $2.0 \mathrm{~m}$ high. Each tank was connected by plastic tubing to bell drinkers. Water consumption per pen was not registered because four pens shared a common source of WL. As in Exp. 1, grower and finisher diets were used; anticoccidial drugs and antibiotic growth promoters were not included in the feeds. Body weight per pen was registered at the beginning and end of the trial and the feed offered and refused was also registered every week to determine the feed intake $(\mathrm{g} / \mathrm{d})$, weight gain $(\mathrm{g} / \mathrm{d})$ and feed conversion. At the end of the experiment, and after a fasting period of $12 \mathrm{~h}$, five broilers from each pen were slaughtered to evaluate carcass weight and its components (breast, legs, thighs, and abdominal fat).

In both experiments, all statistical analysis were conducted using one-way analysis of variance in accordance with a completely randomized design, following the procedures of the general lineal models of SAS (1990). The model used was

$$
\mathrm{Y}_{\mathrm{ij}}=\mu+\mathrm{T}_{\mathrm{i}}+\mathrm{e}_{\mathrm{ij}}
$$

where $Y_{i j}=$ the variable response, $\mu=$ the common mean, $T_{i}=$ the effects of the increasing level of HA and $e_{i j}=$ the random error.

In Exp. 1, there were 35 replicate crates for the growth performance and 15 ileal samples for the nutrient balance analysis per treatment. For nitrogen and energy ileal digestibilities, there were eight replicate samples per treatment and each replicate was the composite sample of three ileal contents of broilers of the same treatment. Percentage results were transformed to arcsine values before analysis. In Exp. 2, for the growth performance analysis, the experimental unit was each pen and there were eight pens per treatment. For carcass analysis, the experimental unit was each broiler and there were 30 replicate birds per treatment. Polynomial contrasts were used to test for linear, quadratic and cubic patterns (Exp. 1) or for linear and quadratic patterns (Exp. 2) in the variable responses. All statements of significance were based on a 
probability of less than 0.05 . Variability in the data was expressed as the standard error of the mean.

\section{RESULTS AND DISCUSSION}

Results of the chemical composition of the WL in Table 1 indicate the presence of HA, FA, and THA in minor quantities, trace amounts of several minerals $(\mathrm{P}, \mathrm{K}, \mathrm{Ca}, \mathrm{Mg}$, and $\mathrm{Na}$ ) and small amounts of nitrogen. It is important to note that in previous studies in the scientific literature, the commercial products tested in broiler chickens also contained different types of HS (humic, fulvic, ulmic and humatomelanic acids) and different trace minerals (Kocabagli et al., 2002; Ozturk et al., 2010; Ozturk et al., 2012). In the present study, because the diets were formulated to cover or exceed the amino acid, mineral and vitamin requirements, it was expected that any difference detected in the variable responses due to the inclusion of WL could be attributed to the HS. Furthermore, the concentration of total bacteria was 69000 unit forming colonies/mL, but the results of total and fecal coliforms and Salmonella were negative.

The daily water consumption was similar among treatments but the consumption of HA, FA, and THA increased linearly $(p<0.01)$ as the WL increased in the drinking water (Table 3). The consumption of HA, FA, and THA increased from 0 to 47.68 , from 0 to 12.52 and from 0 to $60.20 \mu \mathrm{g} / \mathrm{d}$, respectively. Estimations from the reports of Kocabagli et al. (2002) and Taklimi et al. (2012) indicate that the consumption of HS ranged from 0 to 22 and from 0 to $24 \mu \mathrm{g} / \mathrm{d}$, respectively, when fixed amounts of HS were supplemented in the diet of broiler chickens. However, from the research of Ozturk and Coskun (2006) and Ozturk et al. (2010), in which HS were supplemented in the drinking water, it was not possible to estimate the HS consumption since water intake was not reported.

In Exp. 1, the initial and final body weight, daily weight gain and daily feed intake were similar among the broilers allocated to the different levels of WL in the drinking water, but the feed conversion ratio was lowest at $20 \%$ inclusion of WL (Quadratic effect, $\mathrm{p}<0.01$; Table 3). This result closely resembles the lower feed conversion ratio reported by Kocabagli et al. (2002) in broiler chickens fed with a commercial product containing HS from 22 to 42 and 1 to 42 days of age. This finding is also in agreement with the lower feed conversion ratio observed in other studies in which HS were supplemented either in the diet (Rath et al., 2006; Ozturk et al., 2011; Taklimi et al., 2012) or in the drinking water of broiler chickens (Ozturk and Coskun, 2006; Ozturk et al., 2010). A lower feed conversion ratio has also been observed in nursery and growing finishing pigs supplemented with HS in the feeds (Ji et al., 2006; Wang et al., 2008).

The ileal digestibility of nitrogen was not affected but the ileal digestibility of energy showed a quadratic response $(p<0.05)$ due to the increasing levels of WL in the drinking water (Table 4). The ileal digestibility of energy was lower at $0 \% \mathrm{WL}$, there was a slight increase at $10 \% \mathrm{WL}$, followed by a greater increase at $20 \% \mathrm{WL}$, and then there was a slight reduction at $30 \% \mathrm{WL}$. The ileal digestibility was 3.2 and $2.3 \%$ higher in $20 \%$ and $30 \%$ WL compared to the control group. Growing pigs supplemented with HS in the diet showed greater ileal digestibility of crude protein and crude fat and had a tendency for increased ileal digestibility of dry matter, crude fiber and ash (Písaříková et al., 2010). The greater ileal digestibility of energy of broilers agrees with the greater crude fat digestibility found in pigs; however, the lack of effect of the HS on the ileal nitrogen digestibility in broilers do not agree with the enhanced crude protein digestibility in pigs.

The increased length of the mucosal villi of the jejunum and the increased gut length due to the dietary inclusion of HS in broiler (Ozturk and Coskun, 2006; Taklimi et al., 2012) has been associated with the increased digestibility of nutrients due to a reduction of the passage rate of the intestinal content and to increased extension of enzymatic

Table 3. Water and humic acids consumption and growth performance of broiler chickens in Exp. 1

\begin{tabular}{lccccc}
\hline \multirow{2}{*}{ Items } & \multicolumn{4}{c}{ Level of worm leachate $(\%)$} & \multirow{2}{*}{ SEM } \\
\cline { 2 - 5 } & 0 & 10 & 20 & 30 & 7.221 \\
Water consumption $(\mathrm{mL} / \mathrm{d})$ & 351.82 & 322.11 & 319.77 & 338.13 & 0.994 \\
HA consumption $(\mu \mathrm{g} / \mathrm{d})^{1}$ & 0.00 & 15.14 & 30.06 & 47.68 & 0.296 \\
FA consumption $(\mu \mathrm{g} / \mathrm{d})^{1}$ & 0.00 & 4.51 & 8.95 & 12.52 & 1.290 \\
THA consumption $(\mu \mathrm{g} / \mathrm{d})^{1}$ & 0.00 & 19.65 & 39.01 & 60.20 & 27.69 \\
Initial weight $(\mathrm{g})$ & $1,978.4$ & $1,747.1$ & $1,757.6$ & $1,807.6$ & 37.84 \\
Final weight $(\mathrm{g})$ & $3,156.8$ & $3,047.4$ & $3,078.8$ & $3,095.8$ & 1.91 \\
Feed intake $(\mathrm{g} / \mathrm{d})$ & 171.7 & 168.5 & 169.8 & 168.2 & 1.59 \\
Weight gain $(\mathrm{g} / \mathrm{d})$ & 75.3 & 75.7 & 78.8 & 75.2 & 0.038 \\
Feed conversion & 2.29 & 2.27 & 2.16 & 2.26 & \\
\hline
\end{tabular}

SEM, standard error of the mean; HA, humic acid; FA, fulvic acid; THA, total humic acid.

${ }^{1}$ Linear effect, $\mathrm{p}<0.01 .{ }^{2}$ Quadratic effect, $\mathrm{p}<0.05$. 
Table 4. Apparent ileal digestibility of nitrogen and energy, nutrient balance and apparent metabolizable energy corrected to zero nitrogen retention of broiler chickens in Exp. 1

\begin{tabular}{|c|c|c|c|c|c|}
\hline \multirow{2}{*}{ Items $^{1}$} & \multicolumn{4}{|c|}{ Level of worm leachate $(\%)$} & \multirow{2}{*}{ SEM } \\
\hline & 0 & 10 & 20 & 30 & \\
\hline \multicolumn{6}{|c|}{ Apparent ileal digestibility (\%) } \\
\hline Nitrogen & 83.19 & 83.43 & 83.41 & 83.99 & 0.593 \\
\hline Energy $^{1}$ & 74.89 & 75.46 & 77.31 & 76.61 & 1.042 \\
\hline \multicolumn{6}{|l|}{ Dry matter } \\
\hline Intake $(\mathrm{g} / \mathrm{d})$ & 162.00 & 162.00 & 162.00 & 162.00 & - \\
\hline Excretion $(\mathrm{g} / \mathrm{d})^{1}$ & 38.75 & 36.43 & 36.53 & 34.88 & 1.197 \\
\hline Retention $(\%)^{1}$ & 76.08 & 77.51 & 77.45 & 78.47 & 0.727 \\
\hline \multicolumn{6}{|l|}{ Ashes } \\
\hline Intake $(\mathrm{g} / \mathrm{d})$ & 7.14 & 7.14 & 7.14 & 7.14 & - \\
\hline Excretion $(\mathrm{g} / \mathrm{d})$ & 5.88 & 5.55 & 5.55 & 5.42 & 0.166 \\
\hline Retention $(\%)^{1}$ & 18.91 & 22.29 & 22.28 & 26.34 & 1.985 \\
\hline \multicolumn{6}{|l|}{ Nitrogen } \\
\hline Intake $(\mathrm{g} / \mathrm{d})$ & 4.63 & 4.63 & 4.63 & 4.63 & - \\
\hline Excretion (g/d) & 1.79 & 1.73 & 1.77 & 1.68 & 0.060 \\
\hline Retention $(\%)^{1}$ & 61.25 & 63.57 & 63.47 & 65.12 & 1.178 \\
\hline AMEn (kcal/kg) & 3,007 & 3,047 & 3,046 & 3,086 & 25.94 \\
\hline
\end{tabular}

SEM, standard error of the mean; AMEn, apparent metabolizable energy corrected to zero nitrogen retention.

${ }^{1}$ Quadratic effect, $\mathrm{p}<0.05$.

digestion. Furthermore, in rats supplemented with HS, the benefits in weight gain and nitrogen retention observed in two experiments were associated with a greater area of the epithelial surface, greater length of the villi and greater crypt depth (Yasar et al., 2002).

The dry matter excretion showed a quadratic response ( $\mathrm{p}<0.05)$, being highest at $0 \% \mathrm{WL}$, intermediate at $10 \%$ and $20 \% \mathrm{WL}$ and lowest at 30\% WL (Table 4). The ash and nitrogen excretion were similar among treatments. The retention of dry matter, ash and nitrogen and the AMEn showed quadratic responses $(p<0.05)$ relative to the WL levels in the drinking water, being lowest at $0 \% \mathrm{WL}$, intermediate at $10 \%$ and $20 \% \mathrm{WL}$ and highest at $30 \% \mathrm{WL}$. The improved retention of dry matter, ash and nitrogen and AMEn were in the order of $3 \%, 39 \%, 6 \%$, and $2.6 \%$ at $30 \%$ $\mathrm{WL}$ compared to the $0 \% \mathrm{WL}$. The greatest benefit in the ash retention coincides with the increased tibia ash observed in broilers fed a source of HS (Eren et al., 2000). It also agrees with the improved percentage, thickness and hardness of eggshell reported in laying hens and pheasants supplemented with HS (Dobrzański et al., 2009; Ozturk et al., 2009). The improvement in nitrogen retention also coincides with the greater nitrogen retention in rats supplemented with HS (Yasar et al., 2002). In pigs fed diets with added HS a higher nitrogen digestibility was also reported (Písaříková et al., 2010). Furthermore, it was suggested that the reduction of aerial ammonia in pigs supplemented with HS could be attributed to an inhibition of the urease activity in manure ( $\mathrm{Ji}$ et al., 2006); it is possible that the reduction of the urease activity inside the intestine may have contributed to the greater nitrogen retention in broilers used in this research.

The AMEn increased from 3,007 to 3,086 kcal/kg from $0 \%$ to $30 \% \mathrm{WL}$; this means that the supplementation of WL caused the extra release of $79 \mathrm{kcal} / \mathrm{kg}$ of feed. The highest AMEn value at $30 \% \mathrm{WL}$ did not match the highest ileal energy digestibility at 20\% WL. However, the ileal energy digestibility was also significantly improved at $30 \% \mathrm{WL}$, being $2.6 \%$ higher compared to $0 \% \mathrm{WL}$. The AMEn is a better predictor of the energy use in poultry since the ileal digestibility expresses the difference between the energy consumed and the energy found at the terminal ileum (i.e., the energy which disappears in between the mouth and the ileo-cecal valve), while the AMEn represents the energy available for metabolic purposes.

In Exp. 2, the increasing level of WL in the drinking water had quadratic effects $(p<0.05)$ on the final body weight, daily weight gain and feed conversion ratio (Table 5). The highest responses in final body weight and weight gain and lowest feed conversion ratio were observed in broiler chickens receiving $20 \% \mathrm{WL}$ and were in the order of $3.0 \%, 5.5 \%$, and $5.1 \%$ compared to $0 \% \mathrm{WL}$. The daily feed intake, carcass weight and its components were similar among the different levels of WL. The improvements in the productive responses in Exp. 2 are in agreement with the benefits of feed conversion, ileal energy digestibility, the retention of nutrients and AMEn found in Exp. 1. Furthermore, the results are supported by previous studies in which benefits in productive responses in broilers chickens (Ozturk et al., 2010; Ozturk et al., 2011; Taklimi et 
Table 5. Growth performance and carcass weight of broiler chickens in Exp. 2

\begin{tabular}{lcccc}
\hline \multirow{2}{*}{ Items } & \multicolumn{3}{c}{ Level of worm leachate $(\%)$} & \multirow{2}{*}{ SEM } \\
\cline { 2 - 4 } & 0 & 10 & 20 & \\
\hline Growth performance & & & & \\
Initial weight $(\mathrm{kg})$ & 0.63 & 0.60 & 0.62 & 0.035 \\
${\text { Final weight }(\mathrm{kg})^{1}}^{1}$ & 3.46 & 3.46 & 3.56 & 0.036 \\
Feed intake $(\mathrm{g} / \mathrm{d})$ & 190.2 & 193.8 & 190.8 & 5.731 \\
${\text { Weight gain }(\mathrm{g} / \mathrm{d})^{1}}^{1}$ & 101.2 & 102.0 & 106.9 & 2.343 \\
Feed conversion ${ }^{1}$ & 1.88 & 1.90 & 1.79 & 0.056 \\
Weight of carcass and carcass components $(\mathrm{g})$ & & \\
Carcass & $2,186.5$ & $2,185.1$ & $2,239.9$ & 31.54 \\
Breast & 909.4 & 908.9 & 927.9 & 10.99 \\
Thighs & 363.9 & 363.7 & 372.8 & 5.29 \\
Legs & 338.0 & 337.8 & 345.0 & 4.21 \\
\hline SEM,
\end{tabular}

SEM, standard error of the mean.

${ }^{1}$ Quadratic effect, $\mathrm{p}<0.05$.

al., 2012) and laying hens (Yörük et al., 2004; Ozturk et al., 2009) supplemented with different sources of HS were observed.

Several mechanisms of action have been proposed to explain the benefits observed in broiler chickens supplemented with HS. From the reports of Rath et al. (2002) and Taklimi et al. (2012), it is proposed that the benefits of $\mathrm{HS}$ are due to at least four complementary mechanisms: i) The ability to create protective layers over the epithelial mucosal membrane of the digestive tract against the penetrations of toxic and other bacterial contaminated substances; ii) The ability to increase metabolism of protein and microbial carbohydrates based on catalyzing agents by bringing down the $\mathrm{pH}$ of small intestine; iii) Acting as detoxification agents in intestine (due to reducing power in absorption of nitrates, fluorites and heavy metals); and iv) Increasing immune receptors in the digestive tract rather than preserving the beneficial pathogens. Furthermore, the increased relative lymphocyte counts observed in pigs supplemented with HS (Wang et al., 2008) showed that HS may exert a beneficial effect on the immune system of animals, in association with their capability to form complex saccharides in the body, which function as modulators of intercellular interaction.

Other research has shown that HS have strong affinity to bind with several compounds. It was recently found that HS inhibit bacterial and fungal growth, decreasing the effects of aflatoxicosis in broilers (Jansen van Rensburg et al., 2006; Ghahri et al., 2010). Jansen van Rensburg et al. (2006) described that HS could alleviate some of the toxic effects of aflatoxins in growing broilers. Results obtained during in vitro binding studies showed that HS have high mycotoxin adsorption capacity. The protective effect of HS appears to involve the sequestration of aflatoxins in the gastrointestinal tract, reducing their bioavailability. In another study (Ghahri et al., 2010), naturally contaminated diets with aflatoxin were supplemented with several doses of HS, showing that HS at levels of inclusion of $0.2 \%$ and $0.4 \%$ had protective effects on feed efficiency and against liver and bursa damage, as well as some of the serum enzyme activities and serum biochemical changes associated with aflatoxin toxicity in broiler chickens.

In response to HS supplementation, alleviation of the adverse effect of a lethal dose of irradiation (Pukhova et al., 1987) and inhibition of the formation of N-methyl-Nnitrosourea, a mutagenic compound (Badaev et al., 1989) in rats and decreased deposition of heavy metals in chickens (Herzig et al., 2009) after loading may suggest that HS supplementation may benefit well-being under stressing conditions, and consequently, affect poultry performance positively. In the study of Hayirli et al. (2005), the adverse effects of increased caging density were ameliorated with HS supplementation, suggesting that the benefits of HS seemed to be more noteworthy for hens housed in stressing conditions than for hens housed in standard conditions. It has also been suggested that these positive effects could be related to trace elements present in HS having an antioxidant role.

An important issue to consider about the supplementation of HS are the differences in the content of HA and FA, the inclusion level and form (water or feed) and characteristics such as chain length, side chain composition and origin (plant, soil, peat, and coal derived) of HS previously used in poultry (Islam et al., 2005; Ji et al., 2006; Ozturk et al., 2010). In several experiments, commercial products containing HS were used such as Farmagulator Humate in broiler chickens (Eren et al., 2000; Kocabagli et al., 2002) and laying hens (Hayirli et al., 2005; Taklimi et al., 2012). In other research, broilers were supplemented with purified sources of HS (Rath et al., 2006; Ozturk et al., 2011), while in the report of Ozturk et al. (2010), the HS added to the drinking water was obtained from a potassium hydroxide extract of soil that differed in composition to that found in common commercial sources. In addition to these all of differences, in the current experiments, the HS added to the drinking water of broilers was present in a WL originating from the wormcompost of sheep and pig manure.

The findings of the present research indicate that HS in the WL had similar effects on the performance of broiler chickens as the other sources of HS used in previous reports. However, other possible pathways by which other components of the WL may enhance the growth performance and nutrient use in broilers should not be ruled out. For instance, it has been suggested that the microorganisms present on the WL have the ability to produce several plant growth regulators, such as indoleacetic acids (auxins), gibberellins and cytokinins which have been associated with the greater growth of ornamental 
plants, vegetables and enhanced crop yields (Islam et al., 2005; Gomez et al., 2011). It is also likely that other unknown factors coming from the digestive tract of the worms or the resident bacteria inside the digestive tract of the worms are involved in the observed improvements in the growth performance of the birds used in this study. All of these questions deserve further clarification.

\section{IMPLICATIONS}

The addition of WL as a source of HS in the drinking water of broiler chickens had beneficial effects on the growth performance, ileal digestibility of energy and the retention of nutrients, as well as on the AMEn, which agrees with the findings of several previous reports, mainly in broiler chickens, laying hens, pigs and rats. The best results were observed when the WL was mixed at levels of $20 \%$ to $30 \%$ in the drinking water. Several mechanisms of action have been proposed and discussed to explain the benefits of HS on the performance and health of animals, but there are no conclusive explanations. In addition, in future research, it remains important to elucidate whether the HS present in a WL are responsible and the mechanisms of action by which the growth performance and use of nutrients were enhanced in broilers chickens.

\section{REFERENCES}

Badaev, S. A., T. Gichner, F. Pospisil, and J. Veleminisky. 1989. Humic acids inhibit the formation but not the mutagenicity of N-methyl-N-nitrosourea. Mutat. Res. 210:9-13.

EMEA. 1999. Committee for Veterinary Medical Products. Humic acids and their sodium salts, summary report. Committee for Veterinary Medicinal Products. Eur. Agency Eval. Med. Prod. http://www.ema.europa.eu/docs/en_GB/document_library/Max imum_Residue_Limits_-_Report/2009/11/WC500014416.pdf Accessed April 29, 2014.

Eren, M., G. Deniz, S. S. Gezen, and I. I. Turkmen. 2000. Effects of humates supplemented to the broiler feeds on fattening performance, serum mineral concentration and bone ash. Ankara Univ. Vet. Fak. Derg. 47:255-263.

Dobrzański, Z., T. Trziszka, E. Herbut, J. Krawczyk, and P. Tronina. 2009. Effect of humic preparations on productivity and quality traits of eggs from Greenleg Partridge hens. Ann. Anim. Sci. 9:165-174.

Ghahri H., R. Habibian, and M. A. Fam. 2010. Effect of sodium bentonite, mannan oligosaccharide and humate on performance and serum biochemical parameters during aflatoxicosis in broiler chickens. Global Veterinaria 5:129-134.

Gómez, R. S., M. L. Angeles, and J. Becerra. 2011. Alternatives for the recycling of animal manures. Use of wormcompost and other derivatives of wormcomposting. Center of Disciplinary Research in Animal Physiology, National Institute for Research in Forestry, Agriculture and Livestock. Technical Publication No. 14, Queretaro, Mexico. pp. 1-64.

Gomez, S., M. L. Angeles, M. C. Mojica, and S. Jalukar. 2012.
Combination of an enzymatically hydrolyzed yeast and yeast culture with a direct-fed microbial in the feeds of broiler chickens. Asian Australas. J. Anim. Sci. 25:665-673.

Hayirli, A., N. Esenbuga, M. Macit, E. Lacin, M. Karaoglu, H. Karaca, and L. Yildiz. 2005. Nutrition practice to alleviate the adverse effects of stress on laying performance, metabolic profile, and egg quality in peak producing hens: I. The humate supplementation. Asian Australas. J. Anim. Sci. 18:1310-1319.

Herzig, I., M. Navrátilová, J. Totušek, P. Suchý, V. Večerek, J. Blahová, and Z. Zralý. 2009. The effect of humic acid on zinc accumulation in chicken broiler tissues. Czech J. Anim. Sci. 54:121-127.

Islam, K. M. S., A. Schuhmacher, and J. M. Gropp. 2005. Humic acid substances in animal agriculture. Pakistan J. Nutr. 4:126134

Jansen van Rensburg, C., C. E. J. Van Rensburg, J. B. J. Van Ryssen, N. H. Casey, and G. E. Rottinghaus. 2006. In vitro and in vivo assessment of humic acid as an aflatoxin binder in broiler chickens. Poult. Sci. 85:1576-1583.

Ji, F., J. J. McGlone, and S. W. Kim. 2006. Effects of dietary humic substances on pig growth performance, carcass characteristics, and ammonia emission. J. Anim. Sci. 84:24822490.

Joone, G. K. and C. E. van Rensburg. 2004. An in vitro investigation of the anti-inflammatory properties of potassium humate. Inflammation. 28:169-174.

Joone, G. K., J. Dekker, and C. E. van Rensburg. 2003. Investigation of the immunostimulatory properties of oxihumate. Z. Naturforsch. 58:263-267.

Klocking, R. and B. Helbig. 2005. Medical aspects and application of humic substances. In: Biopolymers for Medical and Pharmaceutical Applications (Eds. A. Steinbuchel and R. H. Marchessault). Wiley-VCH Verlag GmbH \& Co. KGaA, Weinheim, Germany.

Kocabagli, N., M. Alp, N. Acar, and R. Kahraman. 2002. The effects of dietary humate supplementation on broiler growth and carcass yield. Poult. Sci. 81:227-230.

Ozturk, E. and I. Coskun. 2006. Effects of humic acids on broiler performance and digestive tract traits. Book of Abstracts of the 57th Annual Meeting of the European Association for Animal Production. Antalya, Turkey. 12:301.

Ozturk, E., I. Coskun, N. Ocak, and G. Erener. 2009. Effects of dietary humic substances on egg production and egg shell quality of hens after peak laying period. African J. Biotechnol. 8:1155-1159.

Ozturk, E., N. Ocak, I. Coskun, S. Turhan, and G. Erener. 2010. Effects of humic substances supplementation provided through drinking water on performance, carcass traits and meat quality of broilers. J. Anim. Physiol. Anim. Nutr. 94:78-85.

Ozturk, E., N. Ocak, A. Turan, G. Erener, A. Altop, and S. Cankaya. 2012. Performance, carcass, gastrointestinal tract and meat quality traits, and selected blood parameters of broilers fed diets supplemented with humic substances. J. Sci. Food Agric. 92:59-65.

Pisarikova, B., Z. Zraly, and I. Herzig. 2010. The effect of dietary sodium humate supplementation on nutrient digestibility in growing pigs. Acta Vet. Brno. 79:349-353.

Pukhova, G. G., N. A. Druzhina, L. M. Stepchenko, and E. E. Chebotarev. 1987. Effect of sodium humate on animals 
irradiated with lethal doses. Radiobiologia 27:650-653.

Rath, N. C., W. E. Huff, and G. R. Huff. 2006. Effects of humic acid on broiler chickens. Poult. Sci. 85:410-414.

SAS Institute Inc. 1990. SAS User's Guide: Statistics, Version 6 4th edn. SAS Inst. Inc., Cary, NC, USA.

Senn, T. L. and A. R. Kingman. 1973. A Review of Humus and Humic Acids. Research Series Report No: 145. South Carolina Agricultural Experiment Station, Clemson, SC, USA.

Stackhouse, R. A. and W. H. Benson. 1989. The effect of humic acid on the toxicity and bioavailability of trivalent chromium. Ecotoxicol. Environ. Safety. 17:105-111.

Taklimi, S. M., H. Ghahri, and M. A. Isakan. 2012. Influence of different levels of humic acid and esterified glucomannan on growth performance and intestinal morphology of broiler chickens. Agric. Sci. 3:663-668.
Wang, Q., Y. J. Chen, J. S. Yoo, H. J. Kim, J. H. Cho, and I. H. Kim. 2008. Effects of supplemental humic substances on growth performance, blood characteristics and meat quality in finishing pigs. Livest. Sci. 117:270-274.

Yasar, S., A. Gokcimen, I. Altunas, Z. Yonden, and E. Petekkaya. 2002. Performance and ileal histomorphology of rats treated with humic acid preparations. J. Anim. Physiol. Anim. Nutr. 86:257-264.

Yoruk, M. A., M. Gul, A. Hayirli, and M. Macit. 2004. The effetcs of supplementation of humate and probiotic on egg production and quality parameters during the late laying period in hens. Poult. Sci. 83:84-88. 